\title{
Tax Payer Compliance of SME (Small and Medium Enterprises) Samarinda Food Sector
}

\author{
Genisha Marta $^{\# 1}$, Anisa Kusuawardhani ${ }^{\# 2}$, Irwansyah ${ }^{\# 3}$

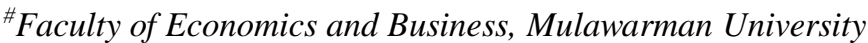 \\ Samarinda, Indonesia \\ ${ }^{1}$ genishamarta@ymail.com
}

\begin{abstract}
The purpose of this study is to empirically test effect of taxpayer perception to the implementation of PP No.46 of 2013, and their awareness on paying taxes on taxpayer compliance of small and medium enterprises. Theoretically the results of this study are expected to enrich and provide several empirical evidences regarding factors that influence the adoption of taxpayer perceive towards tax evasion action, thus it can be useful for academics, practitioners and policy makers. The populations of this study are the small and medium enterprises Samarinda food in Sungai Kunjang district. The sampling method in this study is purposive sampling with any criteria individual taxpayer small and medium enterprises Samarinda food. The analysis of research data on this study uses SPSS 22 (Statistical Package for Social Science). The main findings of the study provide the following information: (1) Taxpayer Perception About the Implementation of GR No.46 of 2013 has no effect on paying taxes on taxpayer compliance, and (2) Awareness of Paying Taxes has effect on Paying Taxes on Taxpayer Compliance The majority of SME do not agree with the change of tariff and the basis of tax calculation. Owners of SME argue that the intent of the Government Regulation number 46 of 2013 cannot educate the public for transparency in tax payments and they argue the socialization of Government Regulation No. 46 of 2013 is still less than the maximum. With maximal socialization can increase awareness and understanding of taxation for owners SME and this also can fulfil the taxation for owners of SME.
\end{abstract}

Keywords - component, Taxpayer Perception, Awareness of Paying Taxes

\section{INTRODUCTION}

Small and Medium Enterprises (SME) is a business unit managed by a group of people, family, or individual, all of whom are the majority of business actors in Indonesia. SME can be easily found in almost all locations, from major cities to suburbs and countryside. SME serves a strategic role in national and regional development, not only because of its contribution to national economic growth, but also because it absorbs workforces in huge quantity. Several business sectors, especially private sectors still demonstrate fairly good performance in that regards, it can be said that SME is a business that survives in variety of conditions.

Paying for tax is the obligation of all citizens and owners of SME. In light of that, the government constantly campaign on the importance of taxation for the development of the nation. Awareness and tax compliance are to be expected from good lawabiding citizens. At this point in time taxation must be understood well due to its fundamental importance to the economy.

Tax by definition is contribution by citizen for state budget based on the law (mandatory) without any reciprocal service that can be directly demonstrated and is used to fund general expense ([5]). Taxation also serves as sources of income for Indonesia, regulatory instrument for future economy, with the purpose of raising and cultivating citizens' awareness and sense of responsibility, since taxation essentially funds the state. Various new laws are issued with the expectation that society would actively participate in the fulfillment of their tax obligation. The government currently aims for a certain private sector that is confirmed to have big potential to become source of tax. That sector is Micro, Small, and Medium Enterprises (MSME) MSME has turnover and profit that are much smaller than major companies.

The effort to uplift the fulfillment of voluntary tax compliance and to push for contribution to state from MSME sector has resulted to the enactment of Government Regulation Number 46 Year 2013 regarding Income Tax Applicable to Income Derived from Business Which Are Received or Obtained by Tax Payers Who Generates Certain Gross Turnover. The implementation of GR No. 46 
Year 2013 aims to provide ease and tax simplification, educating society on administrative order, educating society to be transparent, and provide opportunity for society to contribute to state affair. The new rule on taxation has its advantage, which is a lesser tariff than previously, amounting to $1 \%$ of turnover. GR No. 46 Year 2013 is mandatory for Individual and Corporate Taxpayers with certain gross income, which amounts to less than 4.8 billion derived from business income.

The implementation of GR No. 46 Year 2013 sparks opposing views. The intention of the government to provide ease and simplification upon tax regulation did not get its proper welcome by the society. Based on the research done by [5] the majority of MSME owners disagree with the implementation of GR No. 46 year 2013 due to the bigger amount of tax they have to pay under the new law. Despite of that, taxpayers' perception over GR No. 46 Year 46 in regards to the ease and simplification it provides for the majority of MSME owners is generally positive.

The problem on the level of tax compliance and tax awareness becomes a constant problem in the field of taxation. In Indonesia, the level of tax compliance is low. Such low level of tax compliance becomes very ironic if it is compared to the level of business growth in Indonesia. The growth of MSME undergoes increase each and every year. Yet, the increase on number of MSME is not balanced is with MSME owners' awareness to fulfil its tax obligation.

Attribution theory provides that Tax compliance is linked to taxpayer's behavior in assessing the taxation itself. One's perception in making assessment over somebody else is highly influenced by the external and internal factor of that person. Attribution theory is incredibly relevant to explain such intention. Attribution is a process where one draws conclusion regarding factors that influence the behaviors of others. Attribution theory views individual as amateur psychology that attempts to understand causes to phenomenon occurring before them.

This research assesses taxpayer's perception about the implementation of GR No. 46 Year 2013 and the sense of awareness of tax obligation to the tax compliance of MSME. Such is done because the government has set rules on income tax applicable to income from business that is received and acquired by taxpayers with certain gross circulation as stipulated in GR 46 Year 2013. The purpose to that is to provide ease for society in conducting its tax compliance. In addition, GR Number 46 Year 2013 is also supplemented with procedures of calculation, deposit, and the reporting of income tax with certain gross circulation as set in PMK Number 107 Year 2013. Such a law provides ease for MSME in conducting its tax compliance. The government has also conducted socialization and campaign to improve society's understanding over the benefit of tax for themselves and to pursue the creation of awareness to pay tax in the fulfillment of tax compliance.

\section{RESEARCH METHOD}

\section{A. Research Characteristic}

This research is qualitative and quantitative in nature.

\section{B. Time and Place of Research}

This research was conducted on May 15, 2017 to May 29. This research was conducted in Sungai Kunjang District.

\section{Population and Research Sample}

The population in this research actors of MSME in Sungai Kunjang District. The samples were acquired from the calculation of 60 unit of MSMEs in Sungai Kunjang District.

\section{Procedure}

Data was acquired by providing respondents with. This research relies on closed questionnaires, which is a type of questionnaires that demands a short personal answer from the respondent and a set of answers are already prepared beforehand by researched hence respondents are only asked to pick from one of them. The questionnaires were given by researcher to MSME taxpayers in Sungai Kunjang District.

\section{E. Data, Instrument, and Data Analysis Method}

1) Data and Instrument: Data of this research is primary in nature. The acquiring of the data was done by distributing questionnaires to MSMEs in Sungai Kunjang District. This research utilizes the instrument of questionnaires. Data is gathered from respondents by using questionnaires that 
utilizes Likert Scale which were subsequently used to determine MSME tax compliance, perception on the implementation of GR 46 Year 2013, and tax awareness. The instrument of this research went through validity and reliability test. Instrument test conducted by researcher is used test.

2) Data Analysis Method: This research utilizes primary data to distribute questionnaires to MSME. After data was gathered, researcher conducted instrument test. Test instrument used is used test. Instrument test involves validity test and data reliability test. Data analysis method used is descriptive statistic. Analytical prerequisite test consists of normality test, linearity test, heteroscedasticity test, and multicollinearity test. Hypothesis test employed simple liner regression test and double linear regression test.

\section{RESEARCH RESULT AND ANALYSIS}

\section{Descriptive Statistics}

There are 60 respondents in this research, all of which are 60 unit of MSME in Sungai Kunjang District. Descriptive statistical analysis presented in this research covers Minimum Value, Maximum Value, Mean (M), Deviation Standard (DS).

TABLE 1

\begin{tabular}{|l|l|l|l|}
\hline KET & Y & X1 & X2 \\
\hline Min & 1 & 2 & 2 \\
\hline Max & 5 & 5 & 5 \\
\hline M & 3,85 & 3,72 & 3,56 \\
\hline SD & 0,684 & 0,825 & 0,721 \\
\hline
\end{tabular}

\section{Analytical Prerequisite Test \\ a. Data Normality Test}

The result of normality test can be seen in the table below. Value of Kolmogorov-Smirnov Z amounts to 0,832 with significance value of. Significance of more than 0,05 can be concluded that the data is of a normal distribution

TABLE 2

NORMALITY TEST RESULT

\begin{tabular}{|ll|r|}
\hline \multicolumn{3}{|c|}{ NORMALITY TEST RESULT. } \\
\hline & N & Unstandardized Residual \\
\hline Normal & Mean & 60 \\
Parameter & Std. & .0000000 \\
S $^{\text {a,b }}$ & Deviation & .42389511 \\
Most & Absolute & .069 \\
Extreme & Positive & .069 \\
Differenc & Negative & -.069 \\
es & & .069 \\
Test Statistic & $.200^{c, d}$ \\
Asymp. Sig. (2-tailed) & \\
a. Test distribution is Normal. \\
b. Calculated from data.
\end{tabular}

\section{Classic Assumption Test}

a. Heterocedasticity Test

Result of heteroscedasticity test can be seen in the picture below

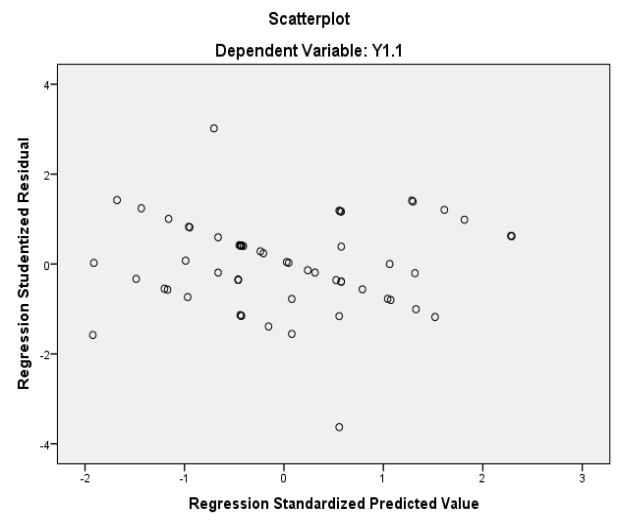

From the picture above, it can be seen that residual values are spread and does not form any particular distributive pattern, which means heteroscedasticity does not occur

a. Multicollinearity Test

Result of multicollinearity test can be seen in table 2 below:

TABLE 3.

Coefficients

\begin{tabular}{|c|l|l|}
\hline \multirow{2}{*}{ Model } & \multicolumn{2}{|l|}{ Collinearity Statistics } \\
\cline { 2 - 4 } & Tolerance & VIF \\
\hline $\begin{array}{c}\text { (Constant) } \\
\text { perception on the } \\
\text { Taxpayers }\end{array}$ & .960 & \\
\hline Amplementation of GR 46 Year 2013 & & 1.042 \\
\hline Awareness of tax obligation & .768 & 1.302 \\
\hline
\end{tabular}

Dependent Variable: y.1

Source: Data SPSS 22

From the table above, it can be seen that VIF value of the three values, which are taxpayer's perception on the implementation of GR No. 46 year 2013, 1,042, and the awareness of tax obligation, 1,032. The VIF value of the three variables are much smaller than 10 , hence it can be concluded that the issue of multicollinearity does not occur among the two independent variables.

a. Hypothesis testing result: Taxpayers perception on GR No. 46 Year 2013 has negative impact on MSME taxpayers compliance.

The impact of taxpayer's perception on the implementation of GR No. 46 year 2013 on MSME taxpayer's compliance

Hypothesis test result shows that variable of taxpayers' perception of the implementation of GR 
No. 46 Year 2013 has level of significance amounting to 0,918 . Which means that Hal is rejected, hence having no impact to MSME taxpayer's compliance because taxpayers' knowledge variable level of significance of is bigger than 0,05 .

Hypothesis test 2 result: the awareness to pay tax has positive impact on MSME tax compliance

The impact of tax awareness to MSME tax compliance

Hypothesis test 3 result shows that awareness variable has level of significance as big as 0,000 . Which means that Ha3 is accepted. Therefore, the tax obligation awareness has an impact on MSME tax compliance due to its less than 0.05 awareness variable level of significance.

\section{ANALYSIS}

Hypothesis testing on the influence of taxpayers' perception on the implementation of GR No. 46 Year 2013 based on the result of the test shows that taxpayers' perception on the implementation of GR No. 46 Year 2013 does not influence small medium enterprises tax compliance. It is the environment surrounding the tax payers that moderates tax compliant behavior toward tax compliance to pay for tax. An individual's perception to make an assessment on something is highly influenced by his/her surrounding environment and therefore the attribution theory is deemed suitable as it tries to find the cause or the drive to one's action. This is because the lack of full understanding over the implementation GR No. 46 Year 2013 does not affect tax compliance. Such is caused by different individual's perception on the implementation of the GR.

The result of the research confirms the research done by [2] the majority of MSME actors do not agree with the implementation of GR No. 46 Year 2013 due to its higher taxation. However, the majority MSMEs perceives the implementation of GR No. 46 Year 2013 in regards to the facility that eases and simplifies taxation as generally positive. There is a correlation between knowledge on tax compliance and taxpayer reporting.

Hypothesis testing on the influence on the awareness to pay tax based on test result shows that the awareness to pay tax does influence MSME taxpayers' compliance. An awareness is a result of learning process from past experiences and gathering of information that is received to gain confidence and to drive an action to be taken. Taxpayers' awareness is related to the perception that covers the paradigm tax function for funding state development, tax utility in providing public goods, as well as fairness and legal certainty in the fulfillment of tax compliance ([6]).

Awareness of tax obligation is a condition where a tax payer, knows, acknowledges, appreciates, and obey the applied rules on taxation as well as having the sincereness and willingness to understand his/her tax obligation ([1]). Taxpayer's awareness is an attempt or mandatory action by MSME taxpayers supplemented by its willingness and personal drive in fulfilling taxation right and obligation in accordance with the applied laws. Such a thing can be seen from the result of this research, that the level of MSME taxpayer awareness is fairly high, this explains the level of willingness of taxpayers in fulfilling its tax obligation well.

The finding of this research is consistent with the finding done by [2] on the factors that influence tax compliance of taxpayer in Tax Service Office (TSO) Pratama East Denpasar which shows that the factor to the awareness of tax obligation and partial penalty have significant influence over taxpayer compliance to pay tax.

\section{CONCLUSION AND RECOMMENDATION}

This research concludes that the implementation of GR No. 46 year 2013 does not affect MSME compliance to tax, meanwhile the awareness of taxi obligation influences MSME tax compliance. It is recommended for the government to lower the current tax rate. TSO Pratama can hold event to improve the awareness of society to pay for tax through socialization and campaign. The next researcher is expected to utilize an indicator that is in accordance with operational theory.

\section{REFERENCES}

[1] Asri, Manik. 2009. Effect of Service Quality, Compliance Cost Tax, and Taxpayer Awareness on Compliance Reporting Taxpayer Agency Registered in Denpasar Tax Office Denpasar. Essay

[2] Gandhys Resyniar. (2014). "Perception of Micro Small Medium Businesses (UMKM) on the Implementation of PP. 46 of 2013 ". Journal of Economics. 
[3] Ghozali, Imam. 2009. SPSS Multivariate Program Application. Diponegoro University. Semarang

[4] Imam Ghozali. (2016). Application of Multivariate Analysis with IBM SPSS 22 Program. 6th Edition Semarang: Diponegoro University Publishing Agency
[5] Mardiasmo. 2011. Taxation Revised Edition 2011. Publisher Andi Yogyakarta

[6] Torgler, Benno. 2007. Tax Compliance, and moral theoretical and empirical analysis. Translation 